\title{
Demographic Factors Associated With Perceptions About Water Safety and Tap Water Consumption Among Adults in Santa Clara County, California, 2011
}

Brianna van Erp, MPH, MPP; Whitney L. Webber, MS; Pamela Stoddard, PhD; Roshni Shah, MPH; Lori Martin, MS, RD; Bonnie Broderick, RD, MPH; Marta Induni, PhD

Suggested citation for this article: van Erp B, Webber WL, Stoddard P, Shah R, Martin L, Broderick B, et al. Demographic Factors Associated With Perceptions About Water Safety and Tap Water Consumption Among Adults in Santa Clara County, California, 2011. Prev Chronic Dis 2014;11:130437. DOI: http://dx.doi.org/10.5888/pcd11.130437 圂.

PEER REVIEWED

\begin{abstract}
The objective of this study was to examine differences in tap water consumption and perceptions of bottle versus tap water safety for Hispanics and non-Hispanic whites, as well as associations with other demographic characteristics. Data are from the Santa Clara County, California, Dietary Practices Survey (2011; N = 306). We used logistic regression to examine associations between demographic characteristics and 1) perceptions that bottled water is safer than tap and 2) primarily consuming tap water. Hispanics were less likely than non-Hispanic whites to primarily drink tap water (OR $=0.33 ; 95 \% \mathrm{CI}, 0.11-0.99)$, although there was no significant difference in perceptions that bottled water is safer between these groups (OR = 0.50; 95\% CI, 0.11-2.27). Hispanics may be an important population for interventions promoting tap water consumption.
\end{abstract}

\section{Objective}

Although total water consumption in the US comes primarily from tap water, a significant percentage comes from bottled water (1). Choosing bottled water over tap water may be related to perceptions of safety, taste, and convenience (2-13). Understanding water consumption and perceptions of water safety can inform interventions like the Centers for Disease Control and Prevention's (CDC) Communities Putting Prevention to Work (CPPW), which promotes tap water as a healthful, fluoridated, low-cost, and environmentally friendly alternative (14). Research has suggested that tap water consumption is lower among Hispanics, younger adults, and women $(1,5,9,11)$. Hispanics may perceive tap water as unsafe given water quality issues in countries of origin among the foreign-born and issues stemming from older plumbing and contamination, especially among those living in lower-income housing or agricultural areas $(3,15)$. In addition, populations with lower socioeconomic status may perceive tap water as less safe $(3,4,6,8-11)$. Previous studies have relied on convenience samples $(3-6,9-11,13)$ and qualitative data $(3,4,9,10,12)$, have been descriptive $(1,3,6,9-13,16,17)$, have focused on water intake only $(1,16,18)$, have included only children $(2,6,18,19)$, or did not include race/ethnicity $(8,10-12,15)$. Our objective was to examine differences in tap water consumption and perceptions of bottled versus tap water safety for Hispanics and non-Hispanic whites, as well as associations with other demographic characteristics, by using a random and representative sample of adults.

\section{Methods}

We used data from the Santa Clara County Dietary Practices Survey administered in 2011. The survey was funded by CPPW to inform Santa Clara County interventions to promote tap water consumption. The survey used the California Dietary Practices Survey, a statewide, cross-sectional, random-digit-dial telephone survey of noninstitutionalized adults conducted since 1989, adding a module on drinking water behaviors for Santa Clara County respondents $(\mathrm{N}=$ 368). The response rate was $22 \%$ and the cooperation rate was $47 \%$. The survey was conducted by the Survey Research Group (Sacramento, California). Specific questions in this analysis were from New York City's Public Opinion Survey on SSBs, Water, and Other Policy Initiatives and underwent cognitive testing before administration (20). 
Outcome variables were 1) thinks bottled water is safer, and 2) primarily drinks tap water. Respondents were asked "Which do you think is safer, bottled water or Santa Clara County tap water or are they about the same?" Responses were categorized as 1) thinks bottled water is safer and 2) does not think bottled water is safer. Respondents also reported the type of water they consumed most often on a typical day. Responses were categorized as 1) primarily drinks tap water (unfiltered tap or filtered tap) or 2) primarily drinks bottled plain water or seltzer (soda) water.

Independent variables included sex, age, education, race/ethnicity, nativity, and income. Race/ethnicity was categorized as non-Hispanic white (hereafter, white), Hispanic, and other (African American, Alaska Native, American Indian, Asian, Pacific Islander, other). Categories for age, education, and income were based on the distribution of responses to ensure sufficient sample size for analysis.

The analytic sample included 306 adults. Respondents with missing data on any variable in the analysis ( $\mathrm{n}=62)$ were excluded. Those with missing data tended to be female, older, more educated, US-born, lower-income, and white; did not think bottled water was safer; and primarily drank tap water. Differences were not statistically significant. See Table 1 for a comparison of characteristics of the analytic sample to the Santa Clara County population. We used logistic regression (weighted) to examine determinants of perceptions of water safety and tap water consumption. Model 1 for tap water consumption included only sociodemographic characteristics; model 2 adjusted for safety perceptions.

This study was certified as exempt from review by the Santa Clara County Health Services Institutional Review Board.

\section{Results}

Respondents were more likely to be female, aged 45 to 64 years, and white (Table 1). Most respondents had some college education or more, an annual household income of $\$ 50,000$ or more, and were US-born. Twenty-nine percent of adults thought bottled water was safer than tap, 68\% primarily drank tap water, and 99\% overall drank any water the previous day (weighted, not shown).

Adults with some college or more were less likely than those with a high school degree or less to think bottled water is safer (odds ratio [OR], 0.32; 95\% confidence interval [CI], 0.11-0.91) (Table 2). The foreign-born were marginally more likely to think bottled water is safer (OR, 2.06; 95\% CI, 0.89-4.77). Hispanics (OR, 0.36; 95\% CI, 0.13-1.02) and foreign-born adults (OR, 0.43; 95\% CI, 0.18-1.04) were marginally less likely to primarily drink tap water than whites or US-born adults, adjusting for other sociodemographic characteristics; after adjustment for perceptions of safety, Hispanics were significantly less likely than whites to primarily consume tap water (OR, 0.33; 95\% CI, 0.11-0.99); results for the foreign-born remained marginally significant (OR, 0.48; 95\% CI, 0.20-1.15). Adjusting for other characteristics, adults who think bottled water is safer were less likely to primarily drink tap water (OR, o.28; 95\% CI, 0.12-0.62).

\section{Discussion}

Most adults (68\%) in Santa Clara County, a diverse, urban county in Northern California, primarily consume tap water. Adjusting for other characteristics, Hispanic adults are less likely to primarily consume tap water than whites. This finding is consistent with a descriptive study based on a national sample, which found that Mexican Americans consumed more bottled than tap water while the opposite pattern was true for whites (1). Another study based on a convenience sample found that Hispanic parents were less likely than non-Hispanic parents to drink tap water (5). Several studies of children or of parent provision of water to children had similar findings $(1,4,18)$.

Although most adults in Santa Clara County primarily consume tap water, nearly 3 in 10 believe that bottled water is safer. Unlike previous studies, we found no difference between Hispanics and whites concerning perceptions of safety of tap versus bottled water, which may be due to differences in question phrasing $(2,4,5)$. Perceptions of safety did not explain differences in water consumption for Hispanics versus whites, and, in fact, differences were only apparent after controlling for safety perceptions; this difference in consumption may be due to factors such as taste, access, or custom. It is unlikely to be due to cost, since tap water is much less expensive.

Consistent with previous studies, less educated adults were more likely to think bottled water is safer, and perceptions that bottled water was safer had an independent, negative effect on primarily consuming tap water (3,4,6,8-11).

This study was subject to limitations. The survey included only households with landline telephones; Hispanics are more likely to live in wireless-only households (21). The study was situated in a single county, which may limit generalizability to other settings.

Several interventions, such as Santa Clara County's Rethink Your Drink and Water to Go campaigns, encourage water consumption (http://www.cdph.ca.gov/programs/wicworks/Pages/WICRethinkYourDrink.aspx, http://www.sccgov.org/sites/sccphd/en-us/Newsandevents/Documents/Water/Water\%20To\%20Go\% 
202013/FAQ_WaterToGo_Oct2013.pdf). Findings suggest that Hispanics are an important target population for such initiatives, especially for efforts promoting tap water consumption.

\section{Acknowledgments}

Funding for the survey was supported in part by a cooperative agreement (\#U5DPoo2500-1) with the CDC and approved by the California Department of Public Health. However, the findings and conclusions in this paper are those of the authors and do not necessarily represent the official position of the CDC.

\section{Author Information}

Corresponding Author: Brianna van Erp, MPH, MPP, Santa Clara County Public Health Department, 976 Lenzen Ave, San Jose, CA 95126. Telephone: (408) 792-5047. E-mail: brianna.vanerp@phd.sccgov.org.

Author Affiliations: Whitney L. Webber, Pamela Stoddard, Roshni Shah, Lori Martin, Bonnie Broderick, Santa Clara County Public Health Department, San Jose, California; Marta Induni, Survey Research Group, Public Health Institute, Sacramento, California.

\section{References}

1. Drewnowski A, Rehm C, Constant F. Water and beverage consumption among adults in the United States: crosssectional study using data from NHANES 2005-2010. BMC Public Health 2013;13(1):1068. CrossRef 通 PubMed 因

2. Onufrak SJ, Park S, Sharkey JR, Sherry B. The relationship of perceptions of tap water safety with intake of sugarsweetened beverages and plain water among US adults. Public Health Nutr 2014;17(1):179-85. CrossRef 圈 PubMed 圈

3. Scherzer T, Barker JC, Pollick H, Weintraub JA. Water consumption beliefs and practices in a rural Latino community: implications for fluoridation. J Public Health Dent 2010;70(4):337-43. CrossRef 国 PubMed 圈

4. Gorelick MH, Gould L, Nimmer M, Wagner D, Heath M, Bashir H, et al. Perceptions about water and increased

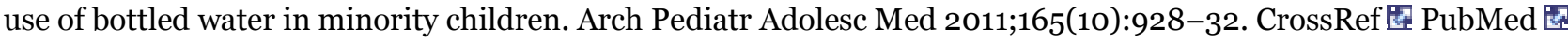

5. Hobson WL, Knochel ML, Byington CL, Young PC, Hoff CJ, Buchi KF. Bottled, filtered, and tap water use in Latino and non-Latino children. Arch Pediatr Adolesc Med 2007;161(5):457-61. CrossRef 圈 PubMed 圈

6. Huerta-Saenz L, Irigoyen M, Benavides J, Mendoza M. Tap or bottled water: drinking preferences among urban minority children and adolescents. J Community Health 2012;37(1):54-8. CrossRef 圈 PubMed 圈

7. Doria MF. Bottled water versus tap water: understanding consumers' preferences. J Water Health 2006;4(2):2716. PubMed 圈

8. Hu Z, Morton LW, Mahler RL. Bottled water: United States consumers and their perceptions of water quality. Int J Environ Res Public Health 2011;8(2):565-78. CrossRef 圈 PubMed 圈

9. Saylor A, Prokopy LS, Amberg S. What's wrong with the tap? Examining perceptions of tap water and bottled water at Purdue University. Environ Manage 2011;48(3):588-601. CrossRef 圈 PubMed 圈

10. de Queiroz JT, Doria Mde F, Rosenberg MW, Heller L, Zhouri A. Perceptions of bottled water consumers in three Brazilian municipalities. J Water Health 2013;11(3):520-31. CrossRef 圈 PubMed 圈

11. Dupont D, Adamowicz WL, Krupnick A. Differences in water consumption choices in Canada: the role of sociodemographics, experiences, and perceptions of health risks. J Water Health 2010;8(4):671-86. CrossRef 圈 PubMed 国

12. Ward LA, Cain OL, Mullally RA, Holliday KS, Wernham AG, Baillie PD, et al. Health beliefs about bottled water: a qualitative study. BMC Public Health 2009;9:196. CrossRef 国 PubMed 国

13. Merkel L, Bicking C, Sekhar D. Parents' perceptions of water safety and quality. J Community Health 2012;37 (1):195-201. CrossRef 圈 PubMed 圈

14. Bunnell R, O’Neil D, Soler R, Payne R, Giles WH, Collins J, et al. Fifty communities putting prevention to work: accelerating chronic disease prevention through policy, systems, and environmental change. J Community Health 2012;37(5):1081-90. CrossRef 圈 PubMed 圈

15. Krieger J, Higgins DL. Housing and health: time again for public health action. Am J Public Health 2002;92 (5):758-68. CrossRef 国 PubMed 国

16. Sebastian RS, Wilkinson Enns C, Goldman JD. Drinking water intake in the US: what we eat in America, NHANES 2005-2008. Food Surveys Research Group dietary data brief no. 7. 
Preventing Chronic Disease | Demographic Factors Associated With Perceptions About ... Page 4 of 6

http://www.ars.usda.gov/SP2UserFiles/Place/1235500o/pdf/DBrief/7_water_intakes_0508.pdf. Accessed September 1, 2011.

17. Roche SM, Jones AQ, Majowicz SE, McEwen SA, Pintar KD. Drinking water consumption patterns in Canadian communities (2001-2007). J Water Health 2012;10(1):69-86. CrossRef 国 PubMed 国

18. Patel AI, Shapiro DJ, Wang YC, Cabana MD. Sociodemographic characteristics and beverage intake of children who drink tap water. Am J Prev Med 2013;45(1):75-82. CrossRef 圈 PubMed 国

19. Park S, Blanck HM, Sherry B, Brener N, O'Toole T. Factors associated with low water intake among US high school students - National Youth Physical Activity and Nutrition Study, 2010. J Acad Nutr Diet 2012;112(9):1421 -7. CrossRef 圈 PubMed 园

20. New York City Department of Health and Mental Hygiene. Public opinion survey on SSBs, water, and other policy initiatives. New York (NY): New York City Department of Health and Mental Hygiene; 2011.

21. Voigt LF, Schwartz SM, Doody DR, Lee SC, Li CI. Feasibility of including cellular telephone numbers in random digit dialing for epidemiologic case-control studies. Am J Epidemiol 2011;173(1):118-26. CrossRef 圈 PubMed 圈

22. US Census Bureau. American Community Survey, 2011, American Community Survey 1-Year Estimates, Tables B01001H B01001I, B05003, B15001, and S1901. http://factfinder2.census.gov. Accessed February 25, 2014.

\section{Tables}

Table 1. Sample Characteristics, Santa Clara County (SCC) Dietary Practices Survey, $2011(\mathrm{~N}=306)$

\begin{tabular}{|c|c|c|c|}
\hline Characteristic & $\mathbf{n}$ & $\% a$ & SCC Adult Demographic, $\%$ b \\
\hline \multicolumn{4}{|l|}{ Sex } \\
\hline Male & 130 & 43 & 50 \\
\hline Female & 176 & 58 & 50 \\
\hline \multicolumn{4}{|l|}{ Age, y } \\
\hline $18-44$ & 101 & 33 & 52 \\
\hline $45-64$ & 129 & 42 & 33 \\
\hline$\geq 65$ & 76 & 25 & 15 \\
\hline \multicolumn{4}{|l|}{ Education } \\
\hline High school graduate or less & 62 & 20 & 31 \\
\hline Some college, associate's degree, or more & 244 & 80 & 69 \\
\hline \multicolumn{4}{|l|}{ Nativity } \\
\hline US-born & 211 & 69 & 54 \\
\hline Foreign-born & 95 & 31 & 46 \\
\hline \multicolumn{4}{|l|}{ Household income, \$ } \\
\hline$<50,000$ & 91 & 30 & 31 \\
\hline$\geq 50,000$ & 215 & 70 & 69 \\
\hline \multicolumn{4}{|l|}{ Race } \\
\hline Non-Hispanic white & 199 & 65 & 38 \\
\hline Hispanic & 48 & 16 & 24 \\
\hline Other & 59 & 19 & 38 \\
\hline \multicolumn{4}{|l|}{ Water safety } \\
\hline Thinks bottled water is safer & 81 & 27 & - \\
\hline Does not think bottled water is safer & 225 & 74 & - \\
\hline
\end{tabular}




\begin{tabular}{|l|r|r|r|r|}
\hline Characteristic & n & $\% \mathbf{~}$ & \multicolumn{2}{|c|}{ SCC Adult Demographic, \% $\mathbf{b}^{\mathbf{b}}$} \\
\hline Water consumption & 218 & 71 & - \\
\hline Primarily drinks tap water & 88 & 29 & - \\
\hline Does not primarily drink tap water
\end{tabular}

a Some percentages may not sum to $100 \%$ because of rounding.

b Santa Clara County demographic estimates are from the US Census Bureau, American Community Survey 2011, 1-Year

Estimates (22).

Table 2. Odds of Perceptions of Water Safety and Tap Water Consumption, Santa Clara County Dietary Practices Survey, $2011(\mathrm{~N}=306)$

\begin{tabular}{|c|c|c|c|c|c|c|}
\hline \multirow[b]{2}{*}{ Characteristic } & \multicolumn{2}{|c|}{$\begin{array}{c}\text { Thinks Bottled Water is } \\
\text { Safer }\end{array}$} & \multicolumn{4}{|c|}{ Primarily Drinks Tap Water } \\
\hline & OR $(95 \% \mathrm{CI})$ & $P$ Value & OR (95\% CI) & $\begin{array}{c}P \\
\text { Value }\end{array}$ & OR $(95 \% \mathrm{CI})$ & $\begin{array}{c}P \\
\text { Value }\end{array}$ \\
\hline \multicolumn{7}{|l|}{ Sex } \\
\hline Male & 1 [Reference] & - & 1 [Reference] & - & 1 [Reference] & - \\
\hline Female & $0.79(0.39-1.58)$ & .497 & $0.75(0.38-$ & 0.413 & $\begin{array}{r}0.76(0.37- \\
1.57)\end{array}$ & .46 \\
\hline \multicolumn{7}{|l|}{ Age, y } \\
\hline $18-44$ & 1 [Reference] & - & 1 [Reference] & - & 1 [Reference] & - \\
\hline $45-64$ & $1.44(0.67-3.09)$ & .354 & $\begin{array}{r}0.53(0.23- \\
1.22)\end{array}$ & 0.134 & $\begin{array}{r}0.58(0.25- \\
1.37)\end{array}$ & .21 \\
\hline$\geq 65$ & $0.85(0.29-2.46)$ & .758 & $\begin{array}{r}0.74(0.29- \\
1.92)\end{array}$ & 0.533 & $\begin{array}{r}0.91(0.36- \\
2.30)\end{array}$ & .84 \\
\hline \multicolumn{7}{|l|}{ Education } \\
\hline High school graduate or less & 1 [Reference] & - & 1 [Reference] & - & 1 [Reference] & - \\
\hline $\begin{array}{l}\text { Some college, associate's degree, } \\
\text { or more }\end{array}$ & $0.32(0.11-0.91$ & .033 & $\begin{array}{r}2.26(0.65- \\
7.92)\end{array}$ & 0.201 & $\begin{array}{r}2.10(0.57- \\
7.81)\end{array}$ & .27 \\
\hline \multicolumn{7}{|l|}{ Nativity } \\
\hline US-born & 1 [Reference] & - & 1 [Reference] & - & 1 [Reference] & - \\
\hline Foreign-born & $2.06(0.89-4.77)$ & .092 & $\begin{array}{r}0.43(0.18- \\
1.04\end{array}$ & 0.060 & $\begin{array}{r}0.48(0.20- \\
1.15)\end{array}$ & .10 \\
\hline \multicolumn{7}{|l|}{ Income, \$ } \\
\hline$<50,000$ & 1 [Reference] & - & 1 [Reference] & - & 1 [Reference] & - \\
\hline$\geq 50,000$ or higher & $0.75(0.27-2.14)$ & .595 & $\begin{array}{r}0.69(0.27- \\
1.79)\end{array}$ & 0.443 & $\begin{array}{r}0.66(0.25- \\
1.78)\end{array}$ & .41 \\
\hline \multicolumn{7}{|l|}{ Race } \\
\hline Non-Hispanic white & 1 [Reference] & - & 1 [Reference] & - & 1 [Reference] & - \\
\hline Hispanic & $0.50(0.11-2.27)$ & .366 & $\begin{array}{r}0.36(0.13- \\
1.02\end{array}$ & 0.055 & $\begin{array}{r}0.33(0.11- \\
0.99)\end{array}$ & .048 \\
\hline Other & $3.49(1.46-8.29)$ & .005 & $\begin{array}{r}1.29(0.47- \\
3.53\end{array}$ & 0.617 & $\begin{array}{r}2.31(0.76- \\
7.07)\end{array}$ & .14 \\
\hline \multicolumn{7}{|l|}{ Water safety } \\
\hline $\begin{array}{l}\text { Does not think bottled water is } \\
\text { safer }\end{array}$ & - & - & - & - & 1 [Reference] & - \\
\hline
\end{tabular}


Preventing Chronic Disease | Demographic Factors Associated With Perceptions About ... Page 6 of 6

\begin{tabular}{|l|r|r|r|r|r|r|}
\hline \multirow{4}{*}{ Characteristic } & \multicolumn{2}{|c|}{$\begin{array}{c}\text { Thinks Bottled Water is } \\
\text { Safer }\end{array}$} & \multicolumn{3}{|c|}{ Primarily Drinks Tap Water } \\
\cline { 2 - 7 } & OR (95\% CI) & P Value & OR (95\% CI) & $\begin{array}{c}\boldsymbol{P} \\
\text { Value }\end{array}$ & OR (95\% CI) & $\begin{array}{c}\boldsymbol{P} \\
\text { Value }\end{array}$ \\
\hline Thinks bottled water is safer & - & - & - & - & $0.28(0.12-$ & .002 \\
& & & & & $0.62)$ & \\
\hline
\end{tabular}

Abbreviation: - , not applicable.

The opinions expressed by authors contributing to this journal do not necessarily reflect the opinions of the U.S.

Department of Health and Human Services, the Public Health Service, the Centers for Disease Control and Prevention, or the authors' affiliated institutions.

For Questions About This Article Contact pcdeditor@cdc.gov

Page last reviewed: June 12, 2014

Page last updated: June 12, 2014

Content source: National Center for Chronic Disease Prevention and Health Promotion

Centers for Disease Control and Prevention 1600 Clifton Rd. Atlanta, GA 30333, USA

800-CDC-INFO (800-232-4636) TTY: (888) 232-6348 - Contact CDC-INFO

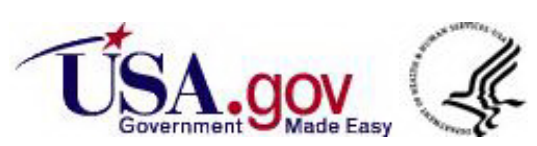

